\title{
Plants that Influences the Socio-cultural of Adis of Arunachal Pradesh
}

\author{
Victor Singh Ayam*, Jami Nyitan \\ Department of Botany, Rajiv Gandhi University, Rono Hills, Doimukh, Arunachal Pradesh-791112
}

\begin{abstract}
Arunachal Pradesh is listed under the global mega-diversity centers. Most of the people are still forest dwellers. Survey was carried out in Adi-dominated areas of Kaying, newly formed Siang district of Arunachal Pradesh. In this article, we discuss about the use of culturally important indigenous biodiversity used by the Adi people as food, religious rites etc. A total of 42 species of wild edible plants were documented. Local people use leaves, stem, fruits, seeds and roots as a part of their diet. Most of the foods are consumed in boiled forms. Few most commonly consumed indigenous plants are Onger (Zanthoxylum rhetsa), Poi (Basella rubra), Dhenkia saag (Diplazium esculentum), Marsang (Spilanthus acmella), Ongin (Clerodendrum colebrookianum), and Rori (herb) and considered most dependable food plants. The other species such as banko, champa, gende, kekir, kopi, koppir, kordoi, mamang, marsang, onger, ongin, oyik, paput etc. are observed as part of both food and ethno-medicines. These plants are also a source of income and as well as the part of adaptive strategies on food security. Some of these species serve as food during famine like Dioscorea. Apart from these, some selected species are used for stupefying and trapping fishes like Riji (Acacia ruguta) and Tamu (Polygonum pubescens), spice, fodder like Tange (Cyathea spinulosa), fiber and packaging materials. Fermented products like Ekkung (Liquid Bamboo shoot) and Eyup (dry Bamboo shoot) are a major part of the diet among the tribes of Adi. Other plants like Rukji (Pteridium aquilinum), which is used in religious ceremony. Result reveals that Adi people are knowledgeable in accessing indigenous biodiversity to use in making culturally, nutritionally and medicinally rich foods.
\end{abstract}

Keywords: Wild plants, Adi community, Socio-culture, Traditional knowledge

\section{INTRODUCTION}

Arunachal Pradesh is located on the Eastern Himalayan region of India is dominated by various ethnic groups. The forest type is enriched with the tropical rain forest and Himalayan ecosystem. The Arunachal Pradesh is also recognized as one of the hot spot biodiversity in the world. The indigenous tribes collectively known as Arunachali had been settling in this hilly state since time immemorial. They are separated in the different pockets of the hilly terrain and confined totheir own source of livelihood, depending fully on natural, and developing the skill of utilizing the nature for the upliftment of theirsociety. Doing so, they evolved a knowledge system for using plants for the prevention and cure of diseases and ailments and for preparing the traditional herbal drugs.

However, due to not having enough skills and organized studies, this valuable data or facts is still within the hedge of indigenous people. Very few have been documented, while much other data is waiting for documentation and scientific screening. First hand documentation and proper scientific screening of this unknown indigenous knowledge may help in the spotting of new drugs in the modern world ( Mibang \& Choudhuri, 2003).

A great extent of wild plant species is used by the Adi tribes including many wild green vegetable leaves, roots, seeds and fruits as food. The using of plants is strongly connected to their traditional and cultural system as they are blessed with knowledge. The benefaction of the wild edibles to the diet and penny-pinching of the local people is often important and therefore emphasis on these species should be privileged. Incorporation of wild plants into the farming system will not only protect biodiversity but also give sufficient food and contribute to the rural economy (Angami et al,2006).

The culturally important plant technologies like chair, table, kitchen utensils, fishing nets and tools, dishes, tools for storage and preservation, etc made of plants are most popular and economically possible among Adis (Singh et al, 2007). They have their own culture traditions, religious rites, food 
habits and medicinalsystem of treatments (Sharma \& Borthakur, 2008). They are reserve house of traditional knowledge which is yet to be demonstrated (Srivastava et al, 2009). In the ongoing paper, we discuss the ethno-botanical and culture related aspects of significant indigenous foods adapted by Adi tribe.

\section{Material AND Methods}

A Field survey was done with the help of knowledgeable local people for collection and study. Plant species were identified from their vernacular names and enthnobotanical information were recorded (Kar, 2004). For selection of priority species, questionnaires were used (Guy-Alain \& Francois, 2001). Informants were selected randomly representing both sex and age groups. Important wild plants were selected on the basis of 'Free listing' method on the principle that the more important species are probably to be mentioned by several respondents (Cotton,1996). Collection of plant samples and preparation of herbarium specimens were done as per of the prescribed methodology (Jain \& Rao, 1977). The specimens were identified with the help of various relevant taxonomic literatures and with consultation of herbarium specimens at State Forest Research Institute, Itanagar (A.P.), Botanical Survey of India (BSI), Itanagar (A.P.) and BSI, Shillong (Meghalaya).

\subsection{Study Area}

The Adi tribe is one of the major tribe of Arunachal Pradesh, located in the Eastern Himalayan hills. The Survey was carried out in most of the districts of Arunachal Pradesh where the Adi Tribes is inhabited most, including the different geographical zones.They are mostly found in sub-tropical region of districts such as West Siang, East Siang, Upper Siang, Siang, Upper Subansiri, and Dibang Villay. To carry out this study, Siang district was selected purposively based on the ethnicity, dependency on forest resources, culturally-laden region, diversity and plant resources, and diversity of ethnic groups among Adi Tribe (Kebo-Kerang, Padam, Minyong and Pangi) (Singh et al, 2012). A representative number of 5 villages namely Kaying, Kerang, Riga, Pangin and Boleng were selected randomly for conducting this study.

\section{RESULTS AND DISCUSSION}

In the present study, about 33 wild plants species has been documented (Table 1). The tree and herb species are mostly used by Adi Tribes, while the climber species are least used, was observed. They mostly consume fruits and leaves however, other plant parts like barks, flowers, tubers, stem etc. were used infrequently. Some of the species like Bangko (Solanum nigrum), Basak oying (Phlogacanthus sp), Marchang (Spilanthes acmella), Nakling (Gynura cusimbua), Okung (Polygonum chinense), Onger (Zanthoxylum armatum), Ongin/Oin (Clerodendrum colebrookianum), Yepetare (Paederia scandens), etc were important for the medicinal purpose. The wild plants play an important role in supplementing other foods, especially in tribal society.

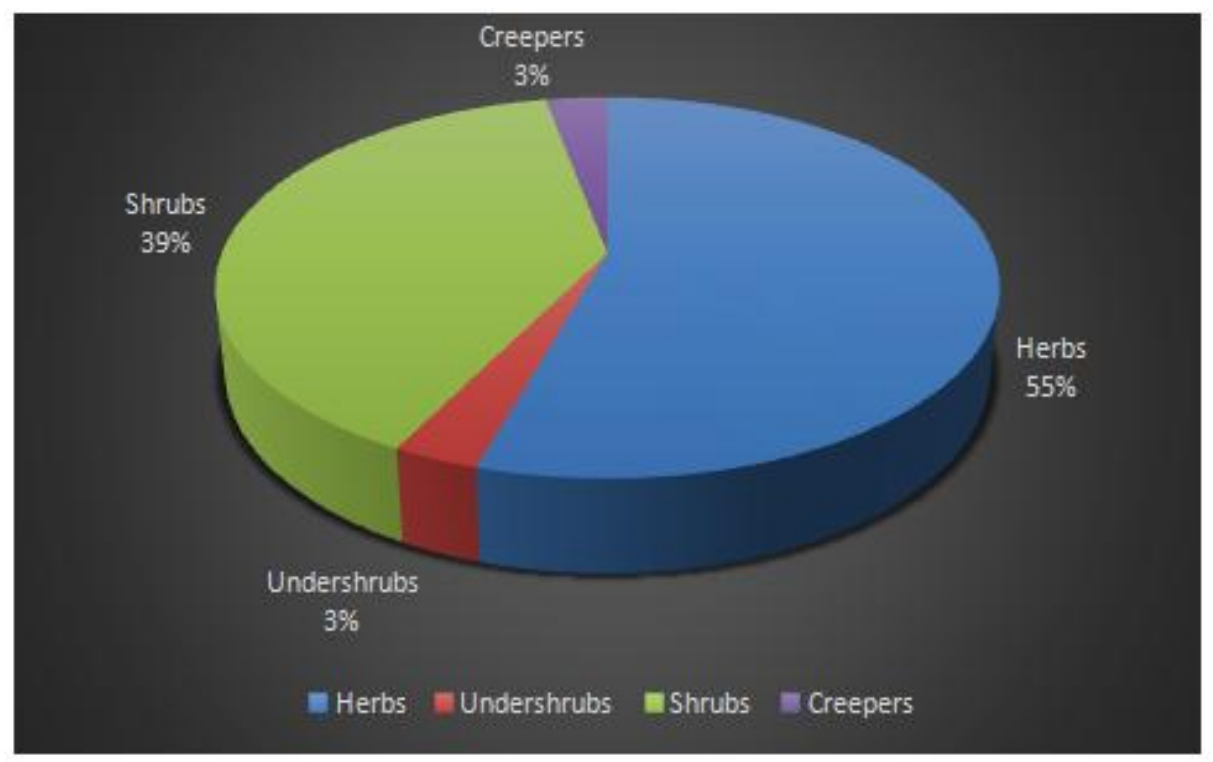

Fig1. Percentage of growth forms of Enthnobotanicals from Adi community 
Table1. Enthnobotanicals explored from Adi community

\begin{tabular}{|c|c|c|c|c|c|}
\hline $\begin{array}{l}\text { Sl. } \\
\text { No. }\end{array}$ & Plant name & Local Name & Family & Habit & Plants used \\
\hline 1 & Alleum hookeri & Dilap & Liliaceae & Herb & Whole plant \\
\hline 2 & $\begin{array}{l}\text { Baliospermum } \\
\text { calycinum }\end{array}$ & Gilgal & Euphorniaceae & Herb & Leaves \\
\hline 3 & Bauhinea variegate & Ogok & Caesalpiniaceae & Herb & Whole plant \\
\hline 4 & Begonia griffithiana & Sudum Meko & Begoniaceae & Herb & Leaves \\
\hline 5 & Blumea fistulosa & Rumdum & Asteraceae & Herb & Leaves \\
\hline 6 & Cardamine hirsute & Tuka & Brassicaceae & Herb & Whole plant \\
\hline 7 & $\begin{array}{l}\text { Clerodendrum } \\
\text { colebrookianum }\end{array}$ & Ongin & Verbenaceae & Shrub & Leaves \\
\hline 8 & Diplezium esculentum & $\begin{array}{l}\text { Takang/Dhekia } \\
\text { saag }\end{array}$ & Athyriaceae & Herb & Tender Leaf \\
\hline 9 & Elastostema sessile & Obur & Urticaceae & Shrub & Leaves \\
\hline 10 & Eryngium foetidium & Adi dhaniya & Apiaceae & Herb & Leaves \\
\hline 11 & Fagopyrum dibotrys & Okung & Polygonaceae & Shrub & Whole plant \\
\hline 12 & Fagopyrum esculantum & Amintatek & Polygonaceae & Shrub & Whole plant \\
\hline 13 & $\begin{array}{l}\text { Glochidion } \\
\text { multiloculare }\end{array}$ & Gaam Oying & Phyllanthaceae & Shrub & Leaves \\
\hline 14 & Gnepalium affine & Paput & Asteraceae & Herb & Tender Leaf \\
\hline 15 & Gynura cripidioides & Gende/illi & Asteraceae & Herb & Tender leaf \\
\hline 16 & Gynura cusimbua & Ogen & Asteraceae & Herb & Tender leaf \\
\hline 17 & Houttuynia cordata & Roram & Saururaceae & Creepers & Tender leaf \\
\hline 18 & Mussaenda roxburghii & Akshap & Rubiaceae & Shrub & Tender leaf \\
\hline 19 & Oxalis corniculata & Phakep & Oxalidaeae & Herb & Whole plant \\
\hline 20 & Paederia foetida & Yepetare & Rubiaceae & Shrub & Leaves \\
\hline 21 & Piper pedicellatum & Rori & Piperaceae & Shrub & Leaves \\
\hline 22 & Plantago erosa & Doni-hankang & Plantaginaceae & Herb & Leaves \\
\hline 23 & Plantago major & $\begin{array}{l}\text { Nane } \\
\text { gitbung }\end{array}$ & Plantaginaceae & Herb & Leaves \\
\hline 24 & Portulaca oleracea & Gubar Oying & Portulacaceae & herb & Whole plant \\
\hline 25 & Pouzolzia hirta & Oyik & Urticaceae & Herb & Tender Leaf \\
\hline 26 & Sida acuta & Tanngom & Malvaceae & Undershrub & Whole plant \\
\hline 27 & Solanum nigrum & Yang-ga & Solanaceae & Herb & Whole plant \\
\hline 28 & Solanum spirale & Bangko & Solanaceae & Shrub & Tender Leaf \\
\hline 29 & Sonchus sp & Ogon & Asteraceae & Shrub & Leaves \\
\hline 30 & Spilanthus acmella & Marsang & Asteraceae & Herb & Tender leaf \\
\hline 31 & Spiradiclis bifida & Sokho & Rubiaceae & Shrub & Leaves \\
\hline 32 & Urtica dioica & Osut-Oyit & Urticaceae & Shrub & Leaves \\
\hline 33 & Zanthoxylum rhesta & Onger & Rutaceae & Shrub & Tender Leaf \\
\hline
\end{tabular}

The plants like Aamun esing (Syzygium cuminii), Bangko (Solanum nigrum), Kopak (Musa sp), Kompe (Prunus persica), Kukto Belo (Ficus sp), Roram (Houttuynia cordata), Rukji (Diplazium esculantum), Tuka (Cardamine hirsute), etcare gathered from wild as well as from kitchen garden for consumption and for sale in the market to supplement their family income.

Some of the plant species serve as food during famine like Engin (Dioscorea). Apart from these, some selected species are used for stupefying and trapping fishes like Riji (Acacia ruguta) and Tamu (Polygonum pubescens), spice, fodder like Tange (Cyathea spinulosa), fiber and packaging materials. Fermented products like Ekkung (Liquid Bamboo shoot) and Eyup (dry Bamboo shoot) are a major part of the diet among the tribes of Adi. Other plants like Ammong Rukji ( Pteridium aquilinum), which is used in religious ceremony. Some others have more uses such as Onger (Zanthoxylum sp), which are used for fishing and also for curing various diseases.

\section{Conclusion}

Gathering and harvesting of food from forest is a usual activity of the Adi tribe. Using of this forest products not only add the food shortage but also would supplement the essential nutritional requirements of the local people. These also improve the economic level of that locality. Some of the important species having medicinal value can be developing into new herbal pharmaceuticals purpose. 
The recapturing of the knowledge and practices may be a significant strategy linked to the conservation of biodiversity. There is still need for documentation of Indigenous Knowledge related to the unexplored cultural heritage regarding traditional plant uses (Kagyung et al, 2010).

\section{ACKNOWLEDGEMENT}

Authors gratefully acknowledge to the local people of the study area for their help and support during the survey and especially to the Head Gaun Burah of Kaying, Kareng, Riga, Pagin and Boleng. Help of Dr. Ayam Victor Singh, Assistant Professor, Rajiv Gandhi University, Arunachal Pradesh, in the study work is gratefully acknowledged.

\section{REFERENCES}

Angami A, Gajurel P R, Rethy P, Singh B and Kalita S K (2006): Status and potential of wild edible plants of Arunachal Pradesh. Indian Journal of Traditional Knowledge, Vol. 5(4), pp-541-550.

Cotton C M (1996): Ethnobtany-Principles and Application. Chichester, Wiley.

Guy-Alain A and Francois M (2001): How Ivory Coast's Malinke ethnic group selects the most beneficial wild fruits. Agroforestry Today, Vol.13, pp-1-2.

Jain S K and Rao R R (1977): A Handbook of Field and Herbarium Technique. Today and Tomorrow Publication, New Delhi.

Kagyung R, Gajural P R, Rethy P and Singh B (2010): Ethnomedicinal plants used for gastrointestinal disease by Adi tribes of Dehang-Debang Biosphere Reserve in Arunachal Pradesh. Indian Journal of Traditional Knowledge, Vol.9(3), pp-496-501.

Kar A (2004): Commonwild vegetables of Aka tribe of Arunachal Pradesh. Indian Journal of Traditional Knowledge, Vol.3(3), pp-305-313.

Mibang T and Choudhuri S K (2003): Ethnomedicines of the Tribes of Arunachal Pradesh. Himalayan Publishers, New Delhi, pp-18-21.

Sharma T P and Borthakur S K (2008): Ethnobotanical observations on Bamboos among Adi tribes in Arunachal Pradesh. Indian Journal of Traditional Knowledge, Vol.7(4), pp- 594-597.

Singh A, Singh K S, Bhardwaj R and Singh A K (2012): Adaptations of culturally and nutritionally important traditional foods in Eastern Himalaya: A case study with Adi women of Arunachal Pradesh. Indian Journal of Traditional Knowledge, Vol.11(4), pp-623-633.

Srivastava R C and Adi Community (2009): Traditional knowledgeof Adi tribe of Arunachal Pradesh on plants. Indian Journal of Traditional Knowledge, Vol.8(2), pp-146-153. 